$\sqrt{B}$

J. Bio-Sci. 29(2): 93-98, 2021 (December)

ISSN 1023-8654

http://www.banglajol.info/index.php/JBS/index

DOI: https://doi.org/10.3329/jbs.v29i2.54958

\title{
INTERPHASE NUCLEAR STRUCTURE IN TEN SPECIES OF PTERIDOPHYTES
}

\author{
MA Mannan ${ }^{1,3}$ and $\mathrm{G}$ Kabir ${ }^{*}$ \\ 1Institute of Biological Sciences, University of Rajshahi, Rajshahi- 6205, Bangladesh \\ 2Department of Botany, University of Rajshahi, Rajshahi-6205, Bangladesh \\ IInformation \& Communication Technology Division, ICT Tower, Agargaon, Dhaka-1207, Bangladesh
}

\begin{abstract}
In thelypterids, interphase chromosomes of Ampelopteris prolifera were accompanied by two or three nucleoli. One nucleolus was seen floating outside the nucleus while other remained attached with the nucleus in annular cells of Christella arida. The mean of chromocentres determined in Adiantum species ranged from 49.8 to 53.6, whereas, it ranged from 46.6 to 49.5 in Pteris species. On the other hand, the value for chromocentres ranged from 62.5 to 123.5 in thelypterids. Nuclear organization was observed to be chromocentric type. In case of interphase nuclear volume it was observed that in Adiantum it was highest in $A$. capillus-veneris followed by $A$. caudatum and A. lunulatum, in Pteris it was highest in $P$ biaurita followed by $P$. vittata and $P$. griffithi, and in case of thelypterids, it was highest in $C$. dantata followed by C. Cylindrothix, A. Prolifera and C. arida.
\end{abstract}

Key words: Chromosome number, Interphase nucleus, Pteridophytes

\section{Introduction}

Among sporophytes, ferns are much more predominant considering the richness of genera and species in a wide range of distribution (Vijaykanth et al. 2018). The increasing number of chromosomal data on the ferns has played a significant role in the identification and phylogenetic affinities of several species and genera (Jim-Mei et al. 2006). The cytological changes due to hybridization, polyploidy and aneuploidy have played an important role in the evolution of plant (Bhavanandan 1981).

Counting of the somatic chromosome number is directly related to interphase nuclear phenotype and heterochromatin percentage for each species of fern. Higher plants, contrary to animals, show species specific organization of chromatin with in the interphase nucleus (Patankar et al. 1985). They also exemplify several unique features such as wide variation in DNA content, absence of facultative heterochromatin and diverse kinds of DNA sequence organization (Ranjekar 1982). Earlier reports in few plant species (Barlow 1977, Nagl 1979a\&b, Nagl and Fusenig 1979, Nagl and Bachmann 1980) have suggested that nuclear DNA content and proportion of different frequency classes of repeated DNA sequences may influence the nuclear organization.

Using various techniques of light, phase contrast, fluorescence and electron microcopy interphase nuclear structure has been investigated. These studies have indicated several interesting features of the interphase nuclei. The aim of the present investigation was to study the interphase nuclear structure and heterochromatin in meristematic cells of ten species of pteridophytes.

*Author for correspondence: gkabir_3000@yahoo.com 


\section{Materials and Methods}

Ten species of pteridophytes were used as material is this study. A brief description of all these plants is presented in Table 1.

Table 1. Habitat and place of collection of ten species of pteridophytes in Bangladesh

\begin{tabular}{|c|c|c|}
\hline Name & Habitat & Place of collection \\
\hline Adiantum capillus-veneris L. & $\begin{array}{l}\text { Dilapidated wall, wet creeks, } \\
\text { sunshades, terrestrial in few } \\
\text { places }\end{array}$ & $\begin{array}{l}\text { Panchagarh, Madaripur, } \\
\text { Rajshahi, Jhenaidah and } \\
\text { Khulna }\end{array}$ \\
\hline A. caudatum $\mathrm{L}$. & Mainly dilapidated brick wall & $\begin{array}{l}\text { Rajshahi, Jhenaidah and } \\
\text { Jessore }\end{array}$ \\
\hline A. lunulatum Burm. & $\begin{array}{l}\text { Old wall, sunshade of buildings, } \\
\text { few places and terrestrial }\end{array}$ & $\begin{array}{l}\text { Dinajpur, Bogra, Jessore, } \\
\text { Rajshahi, Jhenaidah and } \\
\text { Rangpur }\end{array}$ \\
\hline Pteris biaurita L. & $\begin{array}{l}\text { Terrestrial, shade and sunny } \\
\text { places }\end{array}$ & $\begin{array}{l}\text { Dinajpur, Panchagarh, } \\
\text { Rangpur and Nilphamari }\end{array}$ \\
\hline P. griffilhii Hook. & $\begin{array}{l}\text { Terrestrial, wet and shady } \\
\text { dilapidated brick wall }\end{array}$ & Rajshahi \\
\hline P. vittata L. & Brick wall, terrestrial & $\begin{array}{l}\text { Jhenaidah, Rajshahi, } \\
\text { Faridpur and Magura }\end{array}$ \\
\hline Ampelopteris prolifera (Retz.) Reed. & Marshy place, terrestrial & Natore and Rajshahi \\
\hline Christella arida (D. Don) Holtt. & Terrestrial & $\begin{array}{l}\text { Panchagarh, Jhenaidah } \\
\text { and Rajshahi }\end{array}$ \\
\hline C. cylindrothrix (Rosenst.) Holtt. & Terrestrial, moist places & $\begin{array}{l}\text { Madaripur, Satkhira and } \\
\text { Naogaon }\end{array}$ \\
\hline $\begin{array}{l}\text { C. dentata (Forssk.) Brownsey \& } \\
\text { Jermy }\end{array}$ & $\begin{array}{l}\text { Terrestrial, occasionally on } \\
\text { dilapidated wall }\end{array}$ & $\begin{array}{l}\text { Jhenaidah, Rajshahi, } \\
\text { Dinajpur and Barisal }\end{array}$ \\
\hline
\end{tabular}

Interphase nuclear structure was observed from root tip cells, young leaves, tapetal cells and archesporial cells. As there was no unique technique suitable for all the materials different methods were adopted to obtain optimum results. Haematoxylin method of Haque et al. (1976) was found rendering good chromosome stain after several days of preservation in deep fridge.

The root tips were stained following haematoxylin method of Manton (1950) and Haque et al. (1976) with slight modifications. If the chromosomes did not appear with deep stain, then the slide was kept in deep fridge wrapped with blotting paper for few days. Taking out from the refrigerator the slide was kept in room temperature for 3-5 minutes and then again 0.5\% aceto-carmine was added as mounting fluid to the material and gentle heat was applied. If needed $45 \%$ acetic acid was added to clear the cytoplasm. Root tip chromosomes staining after cross section was performed following partially the Burrell's (1939) method. 
Young leaves were collected and cut into several pieces; then kept in saturated solution of PDB and treated for 3-4 h. After pre-treatment, the materials were transferred to 1:3 aceto-alcohols for 24 to $48 \mathrm{~h}$ and then the materials were preserved in $80 \%$ alcohol and kept in refrigerator. The cut pieces of young leaves were hydrolysed with $50 \% \mathrm{HCl}$ for $25-30$ minutes to dissolve the middle lamella of cells and then they were washed thoroughly with distilled water for 5-10 minutes. The washed material was transferred to $95 \%$ alcohol. A cut piece was taken on a clean slide and alcohol was removed with blotting paper and the material was squashed with flat-ended needle in $2 \%$ aceto-carmine. The materials were covered with cover glass and warmed over an alcohol flame and thumb pressure was applied or tapped with a pencil rubber covering the slide with blotting paper to achieve the desired degree of spreading of the cell and therefore, the chromosomes. Excess aceto-carmine was removed with blotting paper.

Chromosome count was also performed from tapetal and archesporial cells. In these cases, aceto-carmine smear technique was adopted. Generally aceto-carminc smear technique was found more convenient than haematoxylin method. For chromocentres counting interphase nuclei were stained from tapetal or young leaf cells following aceto-carmine smear technique.

\section{Results and Discussion}

In Adiantum species, mitosis was observed to be normal. In thelypterids, interphase stage of $A$. prolifera was accompanied by two to three nucleoli. Depending upon the species, interphase nuclei may contain one or more nucleoli and the number may be constant or variable (Wilson 1959). At telophase, nucleolus was also observed in C. arida. Gietler (1936) believed that persistence and disappearance of nucleoli depended on physiological condition that persisted in fresh material and were lost early in culture materials. Reorganization of nucleolus in telophase was reported in Charophyceae (Khatun 1999).

Although mitotic cell division was observed to be normal and regular in the present study but few exceptions were there. In $P$. vittate and in $C$. cylindrothrix anaphase bridges were noticed but the frequency of these happenings seemed to be negligible. In Azolla filiculoides, Nayak and Singh (1989) observed precocious movement of anaphase chromosomes in few cells. The diploid chromosome numbers of $A$. capillus-veneris, A. caudatum and $A$. lunulatum were found to be 60 , in Pteris species it was 58 whereas it was 72 in Ampelopteris and Christella except $C$. dentata which possessed 144 as 4x (Table 2). However, various workers have mentioned the chromosome numbers of these species along with different cytotypes. The mean of chromocenter determined in Adiantum species ranged from 49.8 to 53.6 (Fig. 1 a,b\&c) whereas, it ranged from 46.6 to 49.5 in Pteris species (Figs. 1 d,e\&f). On the other hand the values for chromocenters ranged from 62.5 to 123.5 in thelypterids in the present investigation (Figs. $1 \mathrm{~g}, \mathrm{~h}, \mathrm{i}$ j; Table 2). 
Table 2. Interphase nuclear phenotype and heterochromatin percentages in ten fern species

\begin{tabular}{|c|c|c|c|c|c|c|}
\hline Name of species & 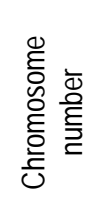 & $\begin{array}{c}\text { Number of } \\
\text { chromocenter } \\
\overline{\mathrm{X}} \pm \mathrm{SE} \\
\text { (Range) }\end{array}$ & $\begin{array}{c}\text { Diameter of } \\
\text { interphase } \\
\text { nucleus, } \overline{\mathrm{X}} \pm \text { SE } \\
\quad(\mu \mathrm{m}) \\
\text { (Range) }\end{array}$ & $\begin{array}{l}\text { Heterochro- } \\
\quad \text { matin } \\
\text { percentage } \\
\text { per nuclear } \\
\text { area, } \overline{\mathrm{X}} \pm \mathrm{SE}\end{array}$ & $\begin{array}{c}\mathrm{NV}\left(\mu^{3}\right) \\
\left(\mathrm{NV}=4 / 3 \pi r^{3}\right) \\
\overline{\mathrm{X}} \pm \mathrm{SE}\end{array}$ & $\begin{array}{c}\operatorname{ICV}\left(\mu^{3}\right), \\
(I C V= \\
N V / 2 n)\end{array}$ \\
\hline A. Capillus-veneris & 60 & $\begin{array}{c}49.8 \pm 0.94 \\
(48-55)\end{array}$ & $\begin{array}{l}12.91 \pm 0.46 \\
(11.20-14.8)\end{array}$ & $36.84 \pm 0.94$ & $1121.49 \pm 0.75$ & 18.69 \\
\hline A. caudatum & 60 & $\begin{array}{c}52.8 \pm 0.88 \\
(50-57)\end{array}$ & $\begin{array}{l}11.54 \pm 0.37 \\
(11.16-14.8)\end{array}$ & $33.03 \pm 0.92$ & $802.24 \pm 1.4$ & 13.37 \\
\hline A. lunulatum & 60 & $\begin{array}{c}53.6 \pm 1.02 \\
(50-58)\end{array}$ & $\begin{array}{c}11.21 \pm 0.10 \\
(10.73-11.84)\end{array}$ & $36.84 \pm 1.05$ & $734.06 \pm 1.21$ & 12.23 \\
\hline P. biaurita & 58 & $\begin{array}{c}46.6 \pm 0.56 \\
(44-50)\end{array}$ & $\begin{array}{l}12.02 \pm 0.22 \\
(11.1-12.95)\end{array}$ & $29.41 \pm 1.72$ & $906.57 \pm 0.75$ & 15.63 \\
\hline P. griffithii & 58 & $\begin{array}{c}48.5 \pm 1.78 \\
(43-53)\end{array}$ & $\begin{array}{l}11.21 \pm 0.07 \\
11.1-11.47)\end{array}$ & $28.91 \pm 0.98$ & $734.06 \pm 1.75$ & 12.66 \\
\hline P. vittata & 58 & $\begin{array}{c}49.5 \pm 0.56 \\
(47-52)\end{array}$ & $\begin{array}{l}11.25 \pm 0.07 \\
(11.1-11.84)\end{array}$ & $28.10 \pm 0.56$ & $741.94 \pm 0.98$ & 12.79 \\
\hline A. prolifera & 72 & $\begin{array}{c}62.5 \pm 0.56 \\
(59-65)\end{array}$ & $\begin{array}{l}8.51 \pm 0.12 \\
(7.55-8.93)\end{array}$ & $34.5 \pm 1.75$ & $321.72 \pm 1.21$ & 4.47 \\
\hline C. arida & 72 & $\begin{array}{c}65.2 \pm 0.95 \\
(60-65)\end{array}$ & $\begin{array}{l}8.44 \pm 0.14 \\
(7.66-8.64)\end{array}$ & $35.37 \pm 1.02$ & $313.85 \pm 0.97$ & 4.36 \\
\hline C. cylindrothrix & 72 & $\begin{array}{c}62.7 \pm 0.73 \\
(60-66)\end{array}$ & $\begin{array}{c}11.14 \pm 0.07 \\
(10.73-11.47)\end{array}$ & $36.02 \pm 1.21$ & $721.68 \pm 1.51$ & 10.02 \\
\hline C. dentata & 144 & $\begin{array}{c}123.5 \pm 0.75 \\
(114-128)\end{array}$ & $\begin{array}{c}14.76 \pm 0.25 \\
(13.24-16.25)\end{array}$ & $37.48 \pm 0.91$ & $1678.61 \pm 1.25$ & 11.66 \\
\hline
\end{tabular}

SE = Standard error, Interphase chromosome volume (ICV), Nuclear volume = NV. 


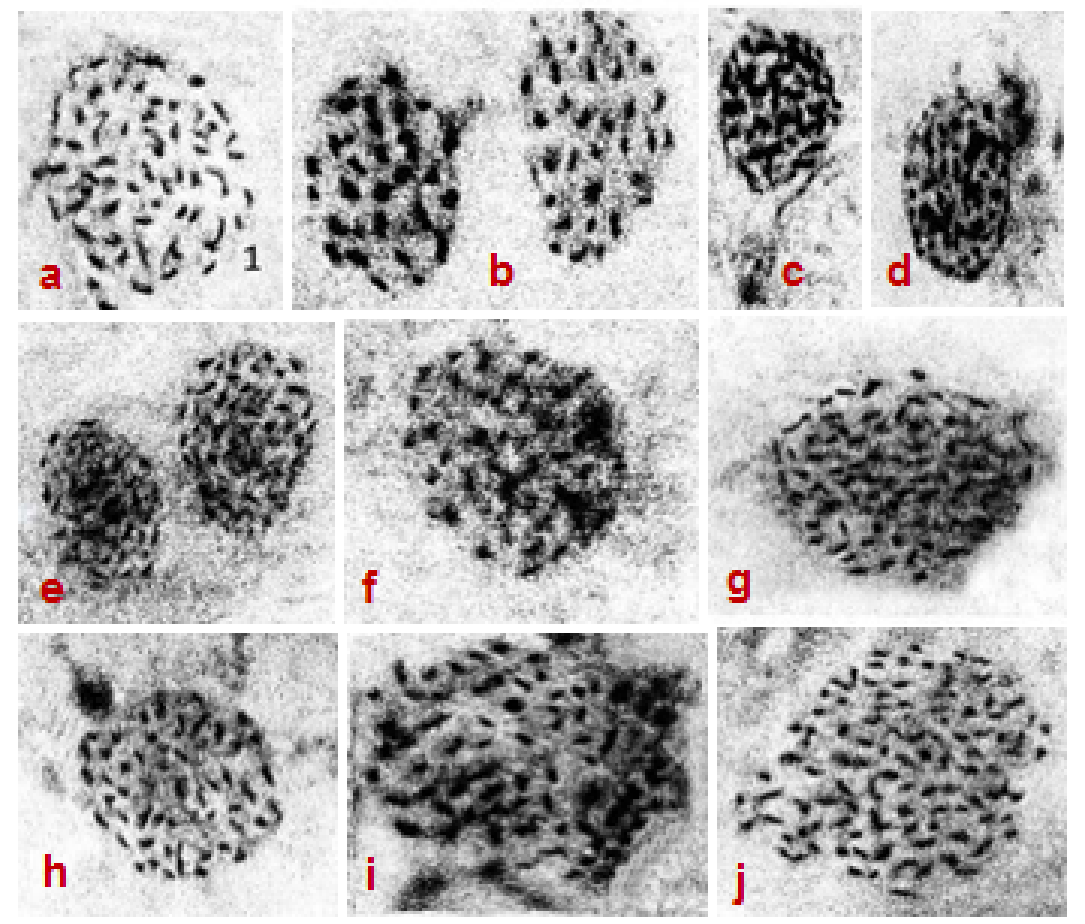

Figs. 1 (a-j): Photomicrographs showing chromocentres in interphase nuclei of ten fern species. a) $A$. capillus-veneris, b) A. caudatum, c) A. lunulatum, d) $P$. biaurita, e) $P$. griffithii, f) $P$. vittata, g) A. prolifera, h) C. arida, i) C. cylindrothrix, and j) C. dentata. Bar $\stackrel{10 \mu m}{\longleftrightarrow}$.

Different classes of heterochromation are found among plants (Vosa 1970, La Cour 1978). It is also stated that in certain species the number of chromocentres is same as the number of chromosomes. However, different views are there. Berrie (1962) opined that heteropycnosis of a particular chromosome region is not constant. The extent of heteropycnotic regions may vary at different stages of the life cycle, and there are also variations among different geographical races of the same species. The number of chromocentres also varies on the basis of staining procedures (Kabir 1986). The nature and functions of heterochromation are uncertain but in both plants and animals it is often associated with the centromere, terminal regions and nucleolar organizing regions of chromosomes and sex chromosomes (Glass 1957).

In case of interphase nuclear volume (Figs. 1a-j, Table 2) it was observed that in Adiantum, it was highest in A. capillus-veneris followed by $A$. caudatum and A. lunulatum; in Pteris, it was highest in P. biaurita followed by $P$. vittate and $P$. griffithii, and in case of thelypterids it was highest in $C$. dentata followed by $C$. cylindrothrix, A. prolifera and C. arida. The chromosome volume ranged from $12.23 \mu^{3}$ to $18.69 \mu^{3}$ in Adiantum species, $12.66 \mu^{3}$ to $15.63 \mu^{3}$ in Pteris species and $4.36 \mu^{3}$ to $11.66 \mu^{3}$ in thelypterids. The heterochromatin percentages were found closer in the species of same chromosome number. 


\section{Conclusion}

Interphase is the metabolic phase of the cell, and obtaining nutrients metabolizes them, replicates its DNA during mitosis and at the same time the chromo-centers which directly correspond with heterochromatin become rich in highly repetitive DNA sequences.

\section{References}

Barlow PW (1977). Determinants of nuclear chromatin structure in angiosperms. Ann. Sci. Nat. Bot., 18: 193-206.

Berrie GK (1962). Cytology and phylogeny of liverworts. Evolution, 17: 347-357.

Bhavanandan K (1981). Studies on the cytology of South Indian Aspidiaceae. Cytologia, 46: 195-207.

Burrel PC (1939). Root tip smear method for difficult materials. Stain Technology, 14(4): 147-149.

Geitler L (1936). Vergleichendeunterschungen den feinerenkren and chromosomes der Cladophoracao. Planta, 25: 530538.

Glass B (1957). Chemical Basis of Heredity. Symposium on the Peaceful Application of Nuclear. In: WD McElroy and B Glass, Eds. (Johns Hopkins Press, Bal-.), New York.

Haque AM, Ali A, Waxuddin M and Khan MA (1976). Squash method for mitotic chromosomes of grasses. Curr. Sci., 45: 382-383.

Jim-Mei L, De-Zhu L and Ding WU (2006). Chromosome numbers of four genera in the Dryopteridaceae. Acta Phytotaxonomica Sinica, 44: 516-522.

Kabir G (1986). Cytomorphological and biochemical differentiation in Cicer species. PhD Thesis. Banaras Hindu University, India.

Khatun W (1999). Nuclear structure, cell division and chromosome morphology of some algal plants. M Phil. Thesis, Rajshahi University, Bangladesh.

La Cour LF (1978). Two types of constitutive heterochromatin in the chromosomes of some Fritillaria species. Chromosoma, 67: 67-76.

Manton I (1950). Problems of cytology and evolution in Pteridophyta. The syndics of the Cambridge Univ. press, London. Nagl W (1979a). Condensed interphase chromatin in plant and animal cell nuclei. Plant Syst. Evol. Suppl., 2: 147-260.

Nagl W (1979b). Interphase chromatin organizations in plant nuclei as determined by genome organization. HoppeSeyler's Z. Physiol. Chems., 360: 321-332.

Nagl W and Bachman K (1980). Condensed chromatin in diploid and allopolyploid Microseris species with different genome genome size. A quantitative electron microscopic study. Theor. Appl. Genet., 57: 107-111.

Nagl W and Fusenig HP (1979). Types of chromatin organization in plant nuclei. Plant Syst. Evol., 2: 221-233.

Nayak SK and Singh PK (1989). Cytological studies on the genus Azolla. Cytologia, 54: 275-286.

Patankar S, Joshi CP, Ranade SA, Bhave M and Ranjekar PK (1985). Interphase nuclear structure in plants: role of nuclear DNA content and highly repeated DNA sequences in chromatin condensation. Proc. Indian Acad. Sci. (Plant Sci.), 94(4-6): 539-551.

Ranjekar PK (1982). Analysis of plant genomes: A Molecular Approach. J. Sci. Ind. Res., 41: 384-393.

Vijaykanth P, Sahaya S, Dominik RS, Irudayaraj V, Kavitha R and Majumder J (2018). Studies on the chromosome number of ferns Kolli Hills, Eastern Ghats, Tamil Nadu, India, Caryologia, 71(4): 380-396.

Vosa CG (1970). Heterochromatin recognition with fluorochromes. Chromosoma, 30: 366-372.

Wilson KA (1959). Sporangia of the fern genera allied with Polypodium and Vittaria. Contri. Gray Herb., 185: 98-127. 